\title{
Comparative Study of the Anatomical Structure of Some Vegetative Organs Allium caspium (pall.) M. Bieb. and Allium tschimganicum B. Fedtsch. Ex Popov Growing in Natural Conditions of Uzbekistan
}

\author{
Akida T. Abdullaeva*, Nargiza K. Rakhimova, Guljan M. Duschanova, Eldor E. Temirov \\ Laboratory Anatomy and Cytoembryology of the Tashkent Botanical Garden Named after Academician F.N. Rusanov, Institute of \\ Botany of the Academy of Sciences, Tashkent, Uzbekistan \\ Email: akida.abdullaeva@mail.ru
}

How to cite this paper: Abdullaeva, A.T., Rakhimova, N.K., Duschanova, G.M. and Temirov, E.E. (2020) Comparative Study of the Anatomical Structure of Some Vegetative Organs Allium caspium (pall.) M. Bieb. and Allium tschimganicum B. Fedtsch. Ex Popov Growing in Natural Conditions of Uzbekistan. American Journal of Plant Sciences, 11, 1398-1404.

https://doi.org/10.4236/ajps.2020.119100

Received: August 15, 2020

Accepted: September 15, 2020

Published: September 18, 2020

Copyright $\odot 2020$ by author(s) and Scientific Research Publishing Inc. This work is licensed under the Creative Commons Attribution International License (CC BY 4.0).

http://creativecommons.org/licenses/by/4.0/ (c) (i) Open Access

\begin{abstract}
The results of a comparative study of the structure of some vegetative organs of $A$. caspium and $A$. tschimganicum growing in natural conditions in Uzbekistan are presented for the first time. During the study of the desert representative $A$. caspium, the following diagnostic, structural features were revealed: ribbing of the peduncle and pedicel; thickening of the outer wall of the epidermis and wavy folding of the cuticle of the parenchymal-bundle type of structure; deep submergence of stomata: extensive core: thinness of the crustal parenchyma, the presence of lactic acid in it; the presence of a highly sclerified sclerinchymal ring between the crustal parenchyma and the central cylinder: the vastness of the core and the presence of hydrocytic cells in it, as well as the similarity of the structure of the stem and pedicel. In this species, a predominance of xeromorphic characters was noted, due to a tendency indicating xerophilization and adaptation to desert conditions. In $A$. tschimganicum, the following mesomorphic diagnostic structural features, opposite to the desert one, were also revealed: roundness of the stem and pedicel, dense folding of the cuticle surface, the presence of lactates in the crustal parenchyma, weak thickening of the crustal parenchyma, and the presence of a weakly sclerized sclerenchymal ring in the central color parenchyma: parenchymal-bundle type of structure, weak thickening of the outer wall of the epidermis and slightly waviness of the cuticle surface, the presence of lactic acid in the crustal parenchyma. Weak submergence of stomata, large-cell crustal parenchyma, extensive, large-cell, thin-walled, poorly sclerified central cylinder, also similarity to the structure of the stem with pedicel, but the
\end{abstract}


presence of a cavity in the stem. The predominance of mesomorphic traits in this endemic species indicated more favorable mountain humid growing conditions were noted.

\section{Keywords}

Anatomy, Stem, Pedicel, Allium caspium, Allium tschimganicum, Samarkand Region, Tashkent Region, Uzbekistan

\section{Introduction}

The species of one of the richest and largest genera of monocotyledonous plants, Allium L. from the Amaryllidaceae family, are represented by about 1200 taxa [1]. This genus is characterized by a high degree of endemism, especially in North America, Asia and the Mediterranean, which represent the main centers of diversity.

Research on rare, endemic plant species of the flora of Uzbekistan is relevant today, given the existing anthropogenic, ecological and other factors to the environment and plant resources. Some of these rare and endemic plants include some onions. Due to the reduction of habitats and the disappearance of rare species, we are conducting a study to identify the causes of extinction at the structural level, due to the adaptation of plants. Most of the onion species are medicinal, food, ornamental and melliferous. Some representatives of the genus Allium possess a unique complex of biologically active substances with a wide spectrum of physiological action. Onions have been shown to inhibit the growth of tumors and microbial cells, reduce the risk of cancer, trap free radicals and protect a person from cardiovascular disease, which is associated with the presence of sulfur-containing compounds and flavonoids.

Bows are widely used in folk medicine in our country, as well as in Mongolian and Indian medicine. Despite this, the creation of drugs from onions is based on the use of a limited number of Allium species (A. cepa L., A. sativum L., A. ursinum $\mathrm{L}$.). All the variety of wild-growing representatives of the genus remains unclaimed by modern medicine. This is largely due to the lack of knowledge of the chemical composition of wild onion species. The chemical composition of onions includes free organic acids, the content of which is low and ranges from $0.15 \%$ to $0.30 \%$ of the raw material. Onion leaves (Allium cepa) contain malic, succinic and citric acids, while their content of the total of acids is $50 \%, 42 \%$ and $8 \%$. The significant content of ascorbic acid in the aboveground green mass during the growing period makes onions especially valuable early vegetable plants. Green leaves of various types of onions on average accumulate 50 - 90 $\mathrm{mg} \%$ of ascorbic acid; from rhizome onions of North Asia, Allium icrodictyon (129.7 mg\%), A. schoenoprasum L. is distinguished by the maximum content of vitamin C. (119.5 mg\%), A. ledebourianum Schuit. \& Schult. (107.2 mg\%) and A. obliquum L. (110 mg\%) [2]. 
The aim of the study is to identify the structural and adaptive features of some vegetative organs in Allium caspium and Allium tschimganicum growing in natural conditions to determine the structural and adaptive diagnostic features.

\section{Materials and Methods}

The belonging of the studied species to the genus Allium was confirmed by the monograph by F.O. Hassanov [3] .

Allium caspium is a perennial bulbous geophyte. Grows in sandy deserts and sands at an altitude of $100-500$ m. Habitat: Caucasus, Iran, Afghanistan, Pakistan, Central Asia: Kazakhstan, Tajikistan, Turkmenistan, Uzbekistan.

The studies were carried out on materials collected from natural habitats (Samarkand region, Takhta-Karacha pass) in 2019 [3].

Allium tschimganicum is also a perennial bulbous geophyte. Grows on gravelly slopes of the middle belt of mountains at an altitude of $1400-1900 \mathrm{~m}$. Habitat: Central Asia, (West Tien Shan): Kyrgyzstan, Uzbekistan. (Tashkent region, Chatkal ridge, Nurekatasay, Kumushkan village) [4] collected in 2019. The vegetative organs (stem and pedicel) of the studied species were collected from the middle layer in the beginning of flowering period were examined.

To study the structure of Allium caspium and Allium tschimganicum, the stem and pedicel were fixed in $70 \%$ ethanol. Cross sections of these organs are made through the middle. Descriptions of the main tissues and cells are given according to $\mathrm{K}$. Esau [5]. The preparations prepared by hand were stained with methylene blue, followed by gluing in glycerin-gelatin [6]. Micrographs were taken with a computer microphoto attachment with a Canon A 123 digital camera under a Motic B1-220A-3 microscope. The cells of the stem and pedicel organs were examined using a light microscope brand MBR-3.

\section{Results and Discussion}

The stem of Allium caspium is rounded-costal in cross section. Epidermal cells are single-row, rounded-oval. The outer wall of the epidermis is thickened. The cuticle surface is slightly wavy. The stomata are deeply submerged, numerous. Under the epidermis there are chlorophyll-bearing cells of the cortex parenchyma, which consist of 4 - 6 rows. The cell walls of the cortex parenchyma are thin. The primary cortex is separated from the central cylinder by a ring of sclerenchyma, the walls of sclerenchymal cells are relatively thickened, $19-21$ vascular bundles are located above the sclerenchymal ring under each rib. The core of the stem is extensive, its cells are rounded, thin-walled, large; $8-10$, consisting of phloem and xylem. There are also several hydrocytic cells in the core. There is a very large cavity in the central part of the core. Vessels are small, thin-walled, the number of which reaches up to 10 (Figure 1).

The pedicel on the cross section is rounded-ribbed, parenchymal-bundle type. The epidermis is single-row, tangently elongated, covered with a thick cuticle. The cuticle surface is slightly folded. The outer wall of the epidermis is thick- 
ened. Most of the pedicel is occupied by the parenchyma. Under the epidermis there is a 3 - 4 row, rounded-oval, thin-walled crustal parenchyma. In the crustal parenchyma above the sclerenchymal ring, large lactic acidae are localized. The boreal parenchyma is separated from the central cylinder by a wide ring of sclerenchyma, the walls of the sclerenchymal cells are thickened, consists of $3-4$ rows. Conducting bundles are located in the crustal parenchyma above the sclerenchymal ring and core, the number of which reaches up to 3 . The vessels are small, thin-walled, 5 - 7 in number (Figure 2).

Thus, when studying the vegetative organs of Allium caspium under natural conditions, the following diagnostic structural features were first identified: similarity in the structure of the stem and pedicel-ribbing; parenchymal-bundle type structure; the thinness of the crustal parenchyma; the presence of a sclerenchymal ring between the parenchymal cortex and the central cylinder. The revealed these characters show the adaptation of the studied species to xerophytic habitat conditions and primitiveness.

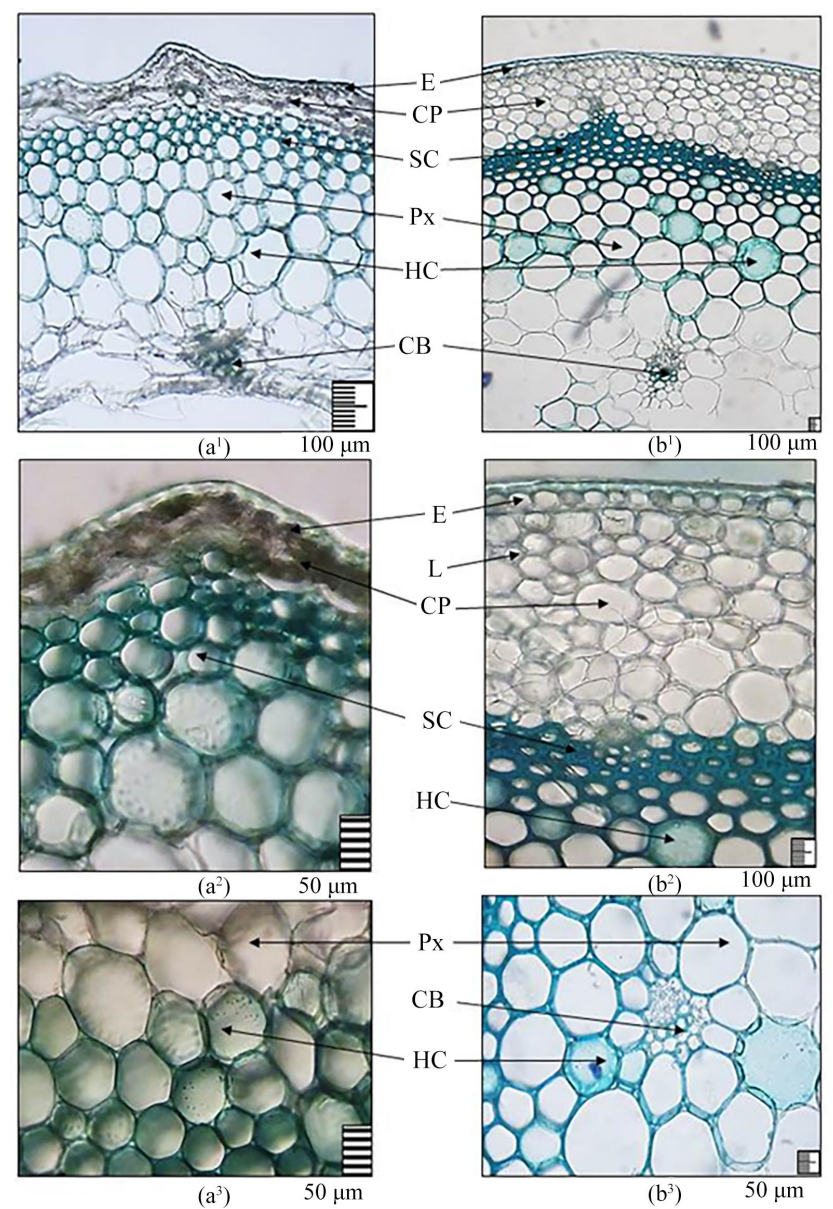

Figure 1. Anatomical structure of the stem Allium caspium $\left(\mathrm{a}^{1}\right)-\left(\mathrm{a}^{3}\right)$ and Allium tschimganicum $\left(\mathrm{b}^{1}\right)-\left(\mathrm{b}^{3}\right)$ : $\left(\mathrm{a}^{1}\right)-\left(\mathrm{b}^{1}\right)$ : detail of stem, $\left(\mathrm{a}^{2}\right)-\left(\mathrm{b}^{2}\right)$ : cortex parenchyma and sclerenchyma, $\left(\mathrm{a}^{3}\right)-\left(\mathrm{b}^{3}\right)$ : parenchymal and hydrocytic cells. Legend: $\mathrm{CB}$-conducting bundles, $\mathrm{CP}$-cortex parenchyma, $\mathrm{E}$-epidermis, $\mathrm{HC}$-hydrocytic cells, L-laterals, $\mathrm{Px}$ - parenchyma, SC—sclerenchyma. 


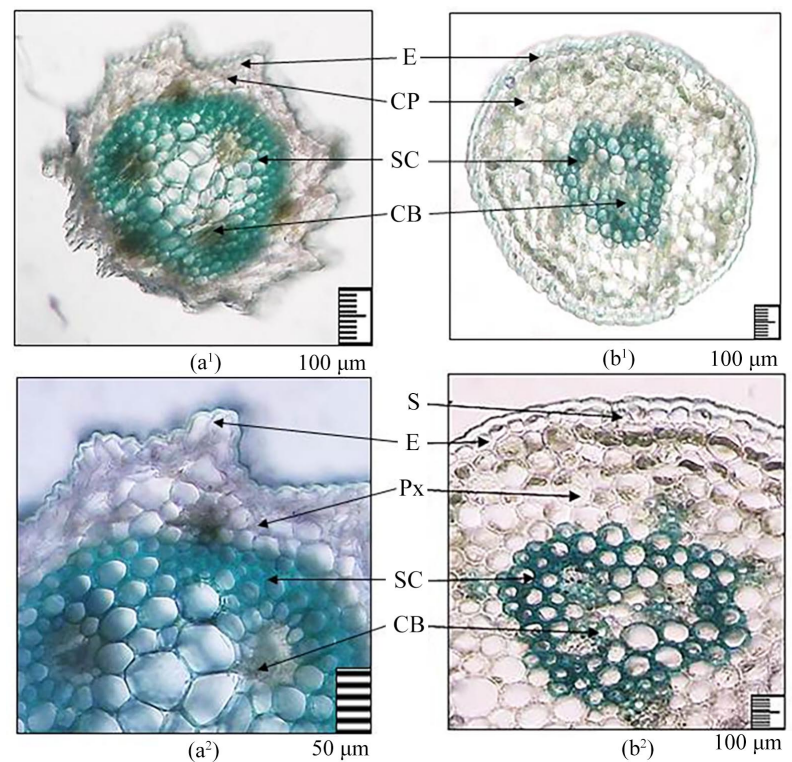

Figure 2. Anatomical structure of the pedicel of Allium caspium $\left(\mathrm{a}^{1}\right)-\left(\mathrm{a}^{2}\right)$ and Allium tschimganicum $\left(\mathrm{b}^{1}\right)-\left(\mathrm{b}^{2}\right)$ : $\left(\mathrm{a}^{1}\right)-\left(\mathrm{b}^{1}\right)$ : general view of the pedicel; $\left(\mathrm{a}^{2}\right)-\left(\mathrm{b}^{2}\right)$ : detail. Legend: $\mathrm{CB}$ - conducting bundles, $\mathrm{CP}$-cortex parenchyma, $\mathrm{E}$-epidermis, $\mathrm{Px}$ - parenchyma, S-stoma, SC-sclerenchyma.

A. tschimganicum: the structure of the stem: rounded in cross section, the epidermis is single-row, rounded-oval, small, the outer wall of the epidermis is slightly thickened, covered with a thin layer of cuticle, the surface of the cuticle is slightly wavy. The stomata are submerged, relatively large. Under the epidermis there is a weakly chlorophyll-bearing, large-cell cortex parenchyma, consisting of 4 - 5 rows, which is separated from the central cylinder by a sclerenchymal ring, consisting of 5 - 7 rows of sclerenchymal cells (Figure 1).

Above the sclerenchymal ring, conducting bundles are localized, tightly adjacent to them. Closer to the epidermis, in one row, there are large lactifiers, which are randomly located. The central cylinder is extensive, large-celled, and thin-walled. Most of the stem is occupied by parenchymal tissue. In the central cylinder, in two circles, there are non-cleared vascular bundles, which are represented by phloem and xylem (Figure 1).

The structure of the pedicel on the cross section is rounded, the epidermis is single-row, rounded, small, the outer wall of the epidermis is slightly thickened. The cuticle surface is highly folded. Stoma (2 - 3) deeply submerged. The bark parenchyma is weakly chlorophyll-bearing, large-celled, 4 - 5 rows, cells of their rounded shape. In the central cylinder there are 2 conducting bundles, which are surrounded by a sclerenchymal ring consisting of sclerenchymal cells, above them there are three conducting bundles (Figure 2).

Thusly, the anatomical structure of the vegetative organs of the endemic species Allium tschimganicum, collected from natural habitats, Tashkent region, Chatkal ridge, Nurekatasai, Kumushkan village was investigated. The study revealed the following structural diagnostic signs: pedicel-parenchymal-bundle type of structure, slight thickening of the outer wall of the epidermis and slightly 
waviness of the cuticle surface, relatively small numerous epidermal and parenchymal cells, the presence of lactic acid in the crustal parenchyma. Weak submergence of stomata, large-cell crustal parenchyma, extensive, large-cell, thin-walled, weakly sclerified central cylinder. The stem has the same structure as the pedicel, but differs in the presence of a cavity in the central cylinder, and is also more sclerified in comparison with the pedicel. The revealed anatomical diagnostic features of the vegetative organs of $A$. tschimganicum indicate its confinement, as well as adaptability to mesophytic growing conditions. For the first time in Uzbekistan, the anatomical structure of the vegetative organs of Allium tschimganicum has been studied. The study revealed the following structural diagnostic signs: in the pedicel-parenchymal-beam type of structure, slight thickening of the outer wall of the epidermis and slightly waviness of the cuticle surface, the presence of lactic acid. Weak submergence of stomata, large-cell crustal parenchyma, extensive central cylinder; in the stem, the stem is similar to the pedicel, differs in a cavity in the central cylinder, also more sclerified in comparison with the pedicel, but the stem has a cavity in the central cylinder. The revealed anatomical diagnostic features of the vegetative organs of $A$. tschimganicum indicate its confinement to mesophytic growing conditions.

When studying the vegetative organs of Allium caspium under natural conditions, the following diagnostic structural features were first identified: similarity in the structure of the stem and pedicel-ribbing; parenchymal-bundle type structure; the thinness of the crustal parenchyma; the presence of a sclerenchymal ring between the parenchymal cortex and the central cylinder. The revealed these characters show the adaptation of the studied species to xerophytic habitat conditions and primitiveness.

\section{Conclusion}

In a comparative study of two species of the genus Allium growing in two different ecological growing conditions (in Uzbekistan), structural and adaptive diagnostic characters were determined. The revealed pronounced signs of xerophilization in Allium caspium indicate the influence of global warming of the planet, especially in desert arid zones, on plant structures due to which there is a gradual disappearance of some plant species. The predominance of mesomorphic characters in the mountain representative Allium tschimganicum indicates its confinement, adaptation and endemicity to mesophytic growing conditions.

\section{Acknowledgements}

The current research is done under the project VA-FA-F5-008 "Scientific bases for the conservation of the gene pool of rare endemic species of the flora of $\mathrm{Uz}$ bekistan ex situ and the biology of their reproduction".

\section{Conflicts of Interest}

The authors declare no conflicts of interest regarding the publication of this paper. 


\section{References}

[1] Govaerts, R., Kington, S., Friesen, N., Fritsch, R., Snijman, D.A., Marcucci, R., Silverstone-Sopkin, P.A. and Brullo, S. (2018) World Checklist of Amaryllidaceae. Facilitated by the Royal Botanic Gardens, Kew. http://wcsp.science.kew.org

[2] Shirshova, T., Beshley, I. and Matistov, N. (2011) Representatives of the Genus Allium as a Promising Source of Biologically Active Substances and Micronutrients. Bulletin of the Institute of Biology. Komi Scientific Center of the Ural Branch of the Russian Academy of Sciences, 10-11, 15-21.

[3] Abdullaeva, A.T. (2020) Structural Features of Some Vegetative Organs of Allium caspium (Pall.) M. Bieb. Growing in Natural Habitat. V International Scientific-Practical Conference on Priority Directions of Science Development, Lviv, Ukraine, 2-3 March 2020, 57-62.

[4] Khasanov, F.O. (2016) Allium L.: Onion. In: Flora of Uzbekistan, Tashkent, 6-119.

[5] Esau, K. (1969) Plant Anatomy. Moscow: Publishing House. Mir, 138-416.

[6] Barykina, R.P., Veselova, T.D., Devyatov, A.G., et al. (2004) Handbook of Botanical Microtechnology (Fundamentals and Methods). Moscow: Publishing House, Moscow State University, 6-68. 